\title{
Article \\ Analysis of Solutions Improving Safety of Cyclists in the Road Traffic
}

\author{
Przemysław Skoczyński (D)
}

Citation: Skoczyński, P. Analysis of Solutions Improving Safety of Cyclists in the Road Traffic. Appl. Sci. 2021, 11, 3771. https://doi.org/ 10.3390/app11093771

Academic Editors: Paweł Droździel, Radovan Madleňák,

Saugirdas Pukalskas, Drago Sever and Marcin Ślęzak

Received: 24 March 2021

Accepted: 20 April 2021

Published: 22 April 2021

Publisher's Note: MDPI stays neutral with regard to jurisdictional claims in published maps and institutional affiliations.

Copyright: (C) 2021 by the author. Licensee MDPI, Basel, Switzerland. This article is an open access article distributed under the terms and conditions of the Creative Commons Attribution (CC BY) license (https:// creativecommons.org/licenses/by/ $4.0 /)$.
Motor Transport Institute, 80 Jagiellońska Str., 03-301 Warsaw, Poland; przemyslaw.skoczynski@its.waw.pl

\begin{abstract}
Cycling safety management is particularly important due to the increasing use of this mode of transport and increasing car traffic flows. Cyclists-travelling on roadways or sharing the space with pedestrians - are exposed to considerable risks for their safety, as well as for the safety of other road users. Comprehensive and effective management of bicycle traffic safety is therefore essential for the protection of this group of road users. The article presents procedures, the implementation of which is aimed at increasing the safety of cyclists and effective implementation of measures to achieve that. The analyses aimed at the selection of appropriate measures and solutions to improve safety of cyclists in the road traffic have been presented. The procedures include: Selection of devices and measures, risk assessment and estimation of the potential to reduce the risk of collisions/accidents involving cyclists, selection of investment measures and devices reducing the risk of cyclists and other road users, implementation methods and monitoring of selected measures reducing the risk of collisions/accidents involving cyclists. The proposals contained in the article fill in the gap existing in this area of knowledge. The analyses conducted and the presented results show that the construction of infrastructure for cyclists is not the only way to improve the safety of this group of road users. Due to the high costs and deficit of the road surface in the road-street cross-section-other forms of measures in this area should also be analyzed.
\end{abstract}

Keywords: road safety; traffic safety; cycling safety; infrastructure for cyclists; traffic accidents

\section{Introduction}

The popularity of the bicycle as a mode of transport has grown rapidly in the recent years, mainly in urban areas. This is undoubtedly a very positive trend towards the goal of sustainable mobility, as well as from the point of view of environmental protection and the increase of the air pollution (especially in urban areas) caused by other vehicles, congestion and limited access to parking spaces [1,2]. Changing the way people travel-including the increasing shift from cars to bicycles-can also contribute to improving the overall health of the population [3]. Attention is also paid to the sociological aspect of using a bicycle, as the ease of travelling by this mode of transport and free interaction, which it facilitates, such as visiting shops or meeting other people, strengthens the sense of community, which is an important element influencing the integration of local communities [4]. It is pointed out, that one of the key factors stimulating cycling is the availability of cycle-friendly infrastructure, meaning such infrastructure which enables comfortable cycling in a safe and attractive traffic environment [1]. The available research shows that cyclists choose their route on the basis of certain preferences-cyclists avoid places perceived as highly dangerous, while they choose cycle paths if available [5].

In Poland, cyclists constitute a small group (2\%) of the road traffic users as compared to, e.g., drivers of passenger cars, but their number is growing every year [6]. The infrastructure in the cities-constantly developed and adapted to the requirements of cycling-encourages more and more people to use bicycles. Due to the growing popularity of this mode of transport and the limitations in access to the public transport, which have recently been experienced in many countries due to the COVID-19 pandemic, the measures 
to increase the safety of cyclists are becoming particularly important, as bicycle traffic is also threatened by possible accidents. When there is a road traffic incident involving cyclists, they are usually the most seriously injured. This is due to the fact that-like pedestrians, mopeds, and motorcyclists - they are not protected by the body of the vehicle. Most often, cyclists do not have additional elements of personal protection, e.g., a helmet or gloves that could save them from certain injuries or reduce their effects. The same applies to additional equipment to increase visibility—such as lights—which are most important outside of built-up areas after dark. Sometimes the infrastructure poses a hazard to cyclists-too high curbs, the lack of marked crossings for cyclists represents real traps.

A completely new challenge for the safety of cyclists is also taking into account the occurrence of autonomous vehicles in the road traffic. Future automated vehicles will have to face the challenge of anticipating the intentions of other road users in order to plan their own behavior without compromising the safety and efficiency of the surrounding traffic [7]. It is connected with the necessity of appropriate programming of reactions of such vehicles to the presence of cyclists in terms of correct perception of cyclists' intentions on the road, as it happens in case of pedestrians [8]. It seems more justified to separate the cycling traffic from the car traffic and to transfer it to the infrastructure dedicated to this group of road users. In order to offer appropriate infrastructure to cyclists taking into account their route preferences, to carry out a systematic assessment of potential and existing routes and to provide cyclists with relevant information for route planning, data generated and collected by mobile phones, especially smart-phones, can now be used [9]. The large volume of available data and the technological tools to collect and analyze them can significantly help to assess the existing infrastructure dedicated to cyclists and to develop an action plan to extend and improve it.

Countries, such as the Netherlands or Denmark-where cycling has been part of everyday life for decades and cycling infrastructure is fully integrated into urban planninghave now become model examples of how to create an attractive and well-functioning environment ensuring the safety of cyclists. The extensive specialist literature on the subject and the available information and instructional material present in great detail a wide variety of tried-and-tested solutions [10-12]. Also, throughout the European Union, projects have been implemented to develop competences aimed at improving the quality of cycling in the cities. An example is the PRESTO (Promoting Cycling for Everyone as a Daily Transport Mode) project, whose aim was to provide a toolkit for creating cyclingfriendly urban environments [13], implementing rational cycling plans [14] and launching dedicated promotional campaigns [15]. It is recognized that new investments and street modifications that take cycling into account ensure [4]:

- friendly, healthy environment,

- future protection against road congestion,

- increasing employee productivity,

- increased profitability of stores and improved access to the public facilities,

- attractive street landscapes and public spaces, including elements of the so-called small architecture,

- $\quad$ efficient use of space.

Danish experience also shows that in many cities where the number of cyclists has increased, the total number of road accidents has decreased more than in other cities [16]. In other words-it is possible to increase bicycle traffic and at the same time improve road safety.

The safety of cyclists can be improved in many ways. The guidelines available for safe bicycle traffic most often focus on [17-19]:

- $\quad$ key principles and design processes oriented towards road users,

- considerations of urban development projects and other measures to improve road safety,

- road traffic regulations for cyclists travelling on the roadways and at points where bicycle paths connect or intersect the roadways for other vehicles,

- infrastructure made available for cycling, such as cycling paths, bicycle lanes, etc., 
- determining bicycle routes in rural areas and recreational and tourist routes,

- maintenance and management of bicycle routes,

- other design issues such as bicycle parking, signposting, integration with public transport, etc.

The literature review shows that at the turn of the second and third decades of the 21st century, the range of possible solutions and devices improving road safety is large and varied, with a significant part of them being solutions in the field of organization and management. However, a more systematic approach to action is needed and solutions should be aimed at those areas and target groups that will have the greatest impact. Research so far has shown that systematic measures focusing on a comprehensive approach are more likely to improve and increase cycling [9]. Meanwhile, despite such many available solutions and road safety devices dedicated to cyclists, there is still no clear algorithm of conduct in selecting measures appropriate to the existing risks and monitoring the effectiveness of the implemented interventions aimed at increasing the safety of this group of road users. To fill in this gap, the article will present a model of selecting interventions and activities aimed at increasing the safety of cyclists in the road traffic.

The group of implemented interventions reducing the risk of cyclists should be selected each time based on the developed procedure. It is a very important and complex element in the process of planning, designing and implementing a safe infrastructure for the cyclists [18]. The aim of this article is to indicate the possibility of creating an algorithm of conduct, including the diagnosis of hazards, planning areas of intervention and selection of solutions, as well as the implementation of measures increasing the safety of cyclists, and then assessing the effectiveness of the measures undertaken.

Cyclists as users of traffic constitute a separate issue to which sufficient attention should be paid to increase their safety on roads. An in-depth analysis of the problem may provide an opportunity to improve the safety of users of this common, healthy, comfortable, and environmentally friendly mode of transport.

\section{Hazards to Cyclists in Poland-Scale of the Problem}

The basis for the development of effective and efficient road safety programs is a diagnosis of the existing situation. Analysis of long-term road safety programs in force in Poland [20,21], the European Union [22,23], or in other countries set as an example in terms of road traffic safety management, such as Ireland [24], Great Britain [25], Australia [26], the Netherlands [27] or Norway [28] shows that the selection of intervention areas and the selection of appropriate countermeasures actions are based on the assessment of the road safety. The review of multiannual road safety action plans prepared by international organizations, such as WHO [29], and the principles of designing, implementing and monitoring these programs $[30,31]$ indicates the need to diagnose road safety situation. Such an analysis should be carried out (depending on the needs) on a macro scale (e.g., on the scale of a given country), micro (e.g., on the scale of a region, voivodship or smaller units of the country's administrative division) and taking into account the specificity of the problem under consideration (e.g., safety of vulnerable road users) [32]). The most important element of the effective road safety management is to know the factors that influence the level of risk. If their impact is determined, then it is possible to mathematically describe this stochastic process and forecast its evolution, which may contribute to more effective prevention of the road accidents and collisions [33].

Data from the Accident and Collision Record System of the Police Headquarters analyzed at the Polish Road Safety Observatory shows that in 2019, 4426 accidents involving cyclists were recorded in Poland, which accounts for $15 \%$ of the total number of accidents [34]. Cyclists rank fourth in terms of the number of victims among all groups of road users classified by the type of transport. In 2019, 258 cyclists were killed ( $9 \%$ of all people killed), and 3999 cyclists were injured (11\% of all injured). The most common reason of road accidents caused in 2019 by the drivers of other vehicles in which a cyclist was injured was failure to give the right of way (1377 accidents, 10 fatalities, 1365 injured 
people). Likewise, the most common cause of road accidents caused by cyclists was failure to give right-of-way (584 crashes, 63 fatalities, 531 injuries). Alcohol is an important factor influencing the occurrence of road accidents involving cyclists. It is often the cyclists themselves who are under the influence of alcohol ( $8 \%$ of accidents involving cyclists) and unfortunately 2019 was the third year in a row when an increase in the number of accidents involving intoxicated cyclists was recorded (by 3\% compared to 2018).

Due to the seasonality of cycling-depending on the season of the year, but also on the time of day-mathematical models can be used to analyze the factors influencing the number of road accidents. For example, selected models can be used to describe the number of road accidents as a function of time of their occurrence per $24 \mathrm{~h}$ [35]. On the other hand, for forecasting the occurrence of road incidents based on historical data on collisions and accidents, taking into account selected factors influencing their occurrence, as well as the number of victims in the area under consideration, one can use, for example, a multiple regression model [36]. The results obtained from the application of the models can be helpful in identifying the directions necessary to undertake interventions and in shaping the overall strategy in the field of road safety.

\section{Laying Out Safe Bicycle Traffic}

The selection of the type of infrastructure for cyclists requires taking into account many urban and transport factors. These solutions should be consistent and safe with those intended for other road users.

The experience gathered in many countries shows that dispersed solutions-unsuitable for cycling, which were characterized by many investments for years-have not proved successful. Only high-quality infrastructure-connected in a coherent network—guarantees a high level of safe bicycle traffic. Thus, excellent quality infrastructure, appropriate for a given location, is essential to ensure a high level of cycling. The space for cyclists should be located away from motor vehicles or effectively separated from them, while maintaining care about the pedestrians. As indicated in [4], the mixing of bicycle traffic with pedestrian traffic on narrow pavements is never acceptable.

Moreover, it is pointed out that taking into account cycling in new investments and in the reconstruction of streets frees up land that can be used more efficiently, for example for the purposes such as houses, shops, or public space. This approach also avoids public opposition resulting from concerns about high car traffic and the associated noise and pollution. To obtain these benefits, new investments and the reconstruction and renewal of streets should be designed so that a third of all journeys are made by bicycle. This goal is achievable if the right design approach is followed.

It should be remembered that it is also particularly important to minimize conflicts between cyclists and other road users and the availability of space on the demarcation lines. For example, sections of roads with one-way traffic, where the speed limit is $30 \mathrm{~km} / \mathrm{h}$, or entire areas with such traffic organization, may be a strong argument to make them accessible for two-way cycling, while maintaining one-way traffic of other vehicles. It requires introducing appropriate changes in the traffic organization on a given road section or in a given area. The choice of the type of infrastructure for bicycles should take into account:

- functional and spatial connections of the designed bicycle route,

- development of the cross-section of the street in demarcation lines,

- road and traffic conditions (vehicle traffic volume, their speed and traffic distribution, as well as the existing and forecasted bicycle and pedestrian traffic, if a solution of shared use of the road for cycles and pedestrians is chosen).

The review of foreign and domestic experiences in the field of safe bicycle traffic organization $[10,11,13,16,17,19]$ shows - among the others-that bicycle traffic may take place on the road, while maintaining the safety conditions of its participants, with an acceptable speed of up to $30 \mathrm{~km} / \mathrm{h}$ and road traffic intensity of up to 2500 vehicles/day (v/d). In the permitted speed range of $30-50 \mathrm{~km} / \mathrm{h}$ and the traffic intensity of up to $5000 \mathrm{v} / \mathrm{d}$ the choice of the location of infrastructure for cyclists along the road (street) 
and the type of this infrastructure should be determined individually, taking into account local conditions. For the traffic speeds above $50 \mathrm{~km} / \mathrm{h}$, bicycle traffic should be absolutely separated from the road. When the traffic intensity of vehicles $\mathrm{N}>2500 \mathrm{v} / \mathrm{d}$, and the permissible speed $>50 \mathrm{~km} / \mathrm{h}$, then-regardless of the type of area (built-up/non-builtup)_cycling should take place outside the road [18]. With pedestrian traffic of over 200 people/h, it is not allowed for pedestrians and cyclists to use the common area. The criteria for segregating cycling from other vehicles (in built-up areas) adopted under Polish conditions are presented in Table 1.

Table 1. Recommended criteria for the segregation of bicycles and other vehicles [18].

\begin{tabular}{|c|c|c|}
\hline Permissible Vehicles' Speed & $\begin{array}{l}\text { Conditions for Allowing } \\
\text { Mixed Traffic as a Function } \\
\text { of the Value of Vehicle } \\
\text { Traffic Intensity }\end{array}$ & $\begin{array}{l}\text { Proposed Technical and } \\
\text { Organizational Solutions }\end{array}$ \\
\hline $\begin{array}{l}\quad \leq 30 \mathrm{~km} / \mathrm{h} \\
\text { and calm traffic zones } \\
\text { (residential and "zone 30") }\end{array}$ & $\begin{array}{l}\text { traffic intensity } \\
\quad \leq 2500 \mathrm{v} / \mathrm{d}\end{array}$ & $\begin{array}{c}\text { bicycle traffic on the } \\
\text { carriageway (mixed traffic, } \\
\text { bicycle counter-traffic, bicycle } \\
\text { counter-lane, bicycle lane) }\end{array}$ \\
\hline \multirow{2}{*}{$30 \div 50 \mathrm{~km} / \mathrm{h}$} & \multirow{2}{*}{$\begin{array}{l}\text { traffic intensity } \\
\quad>2500 \mathrm{v} / \mathrm{d}\end{array}$} & $\begin{array}{l}\text { bicycle traffic on the } \\
\text { carriageway (counter-lane for } \\
\text { bicycles, bicycle lane) }\end{array}$ \\
\hline & & $\begin{array}{c}\text { off the carriageway (bicycle } \\
\text { path, bicycle path and } \\
\text { pedestrian path }{ }^{*} \text { ) }\end{array}$ \\
\hline$>50 \mathrm{~km} / \mathrm{h}$ & $\begin{array}{c}\text { mixed traffic poses a high risk } \\
\text { absolutely recommended } \\
\text { paths for bicycles outside } \\
\text { the carriageway }\end{array}$ & $\begin{array}{l}\text { bicycle traffic outside the } \\
\text { carriageway (bicycle path, } \\
\text { bicycle path and } \\
\text { pedestrian path *) }\end{array}$ \\
\hline
\end{tabular}

*/ in situations resulting from local conditions, e.g., road safety hazards for cyclists and/or the need to maintain the continuity of the bicycle path.

An important issue related to the choice of the type of infrastructure for cyclists is the problem of a shared path for bicycles and pedestrians. Regardless of the traffic intensity and speed limit, it is not recommended that the path should be shared by bicycles and pedestrians when their combined traffic exceeds a total of 10 bicycles and pedestrians/hour and traffic intensity $>10,000 \mathrm{v} / \mathrm{d}$ [37]. According to the criteria adopted in the Dutch Cycle Design Guidelines [10], the sharing of the traffic space by pedestrian and cyclist depends on the volume of pedestrian traffic. With the intensity of pedestrian traffic below 100 people $/ 1 \mathrm{~h} / 1 \mathrm{~m}$ of the width of the cross-section of the pedestrian zone, full integration of pedestrian and cyclist traffic is permissible. The volume of pedestrian traffic from 100 to 160 people $/ 1 \mathrm{~h} / 1 \mathrm{~m}$ of the cross-section is an indication for separating the traffic of pedestrians and cyclists by designating separate zones on the pavement: for pedestrians and cyclists (painted lines or the color or texture of the pavement). With a pedestrian traffic intensity of 160-200 people/1 h/1 m of the cross-section, it is required to physically separate bicycle traffic from the pedestrian traffic zone. The volume of pedestrian traffic exceeding 200 people/hour/1 $\mathrm{m}$ is a strong contraindication to the use of the common area by pedestrians and cyclists.

Non-investment activities are a current trend in countries with a high level of automotive and economic development and the development of infrastructure for cyclists. Laying out and building paths for bicycles outside the road is an action undertaken in exceptional situations, because they involve high costs and the need to transform the cross-sections of roads and streets. This is what is done when it is necessary to create major cycle routes and to prioritize and give high technical standards to the infrastructure for cyclists. Due to the low costs of project implementation, the ease of its implementation and the possibility of quick adaptation to changing needs, the so-called "soft measures" consisting in the 
separation of various forms of cycling lanes on the carriageway and facilities for cyclists at intersection entrances are much more frequent.

\section{Measures to Increase the Safety of Cyclists and Other Road Users}

The set of measures to increase the safety of cyclists and other road users has been organized into four groups:

1. Spatial planning measures:

- integration of the network of bicycle routes in the spatial planning documents, including the voivodship spatial development plans, local development plans, studies of conditions and directions of spatial development in the cities and communes and metropolitan areas,

- development of urban structures with spatial layouts maximally limiting the role of car transport and improving the conditions for travelling by public transport, on foot or by bike,

- development of road and street routes enabling safe access to schools, which has a great importance for transport and ecological education of the youngest cyclists (this is also an activity in the field of education and promotion);

2. Traffic organization and management measures:

- transformation of the traffic organization system, resulting in the elimination of heavy traffic outside the area of dense urban development,

- segregation of cycling and pedestrian traffic from car traffic, which creates conditions for the improvement of quality of public space in which infrastructure dedicated to cyclists is located,

- $\quad$ speed management in the road system in terms of creating friendly conditions for bicycle traffic, including application of sectional traffic calming so that driving at high speeds is physically difficult or even impossible, but traffic calming measures introduced in the carriageway cross-section should not disturb cycling (e.g., sinusoidal road hump with bypass),

- area traffic calming in the form of residential zones and " $30 \mathrm{~km} / \mathrm{h}$ " reduced speed zones, in the areas where an improvement of cyclists' and pedestrians' safety is the most desirable; this applies mainly to residential areas, city centers, school neighborhoods and other educational institutions, protected areas (it is also a spatial planning measure),

- managing the visibility and lighting of roads and junctions to ensure good perception of each other's traffic participants at the junction by bringing the different types of traffic to intersections that are clearly visible from a distance (e.g., by using raised crossings) for both cyclists and car drivers,

- traffic calming at the crossing of roads with heavy traffic through small towns and villages;

3. Cycling infrastructure measures:

- completing the missing sections of infrastructure for cyclists in the network of existing bicycle routes (e.g., in the form of bicycle paths and/or bicycle lanes),

- introducing counter-lanes and bicycle counter-traffic on the selected streets, considering the necessary changes in the organization of traffic on the adjacent road sections (as part of calming traffic in the city or district),

- inspections of all intersections with traffic lights and infrastructure for bicycles in terms of improving the conditions and safety of bicycle traffic,

- introduction of traffic calming measures on the cycle path in the close surroundings of the intersection of different types of traffic, especially in places where sufficient visibility cannot be ensured (e.g., with chicanes, narrowing, cycle track deflecting, road humps, rumble strips, etc.), 
- taking into account point elements forming a coherent system of interconnections, such as bicycle parking, service points for cyclists with appropriate road markings (this is also a spatial planning measure),

- introduction of collision-free traffic phases and additional devices for cyclists (including bicycle locks, dedicated traffic lights for cyclists, two stage left turn), taking into account priorities for bicycle traffic,

- constant monitoring of the technical condition of the network of routes for cyclists,

- monitoring the behavior of cyclists in the road traffic,

- periodic and continuous measurements of bicycle traffic intensity,

- monitoring hazards to cyclists on the road network;

4. Activities in the field of education and promotion:

- $\quad$ support for programs promoting safe travel to school, considering the possibility of safe travel to school by bicycle and the use of experiences and examples of "good practices" in this field,

- bike sharing programs creating,

- campaigns and promotional activities (in the media and on the Internet) regarding the safe use of a bicycles by children and adults,

- competitions for children and teenagers on safe cycling,

- support for education in the field of preparing primary school children to obtain bicycle driving licenses.

The experience so far shows that only systemic measures, taking into account coherent actions from different measures groups, bring about the desired results.

\section{Selection of Investment Measures and Equipping Roads with Devices Increasing Safety of Cyclists and Other Road Users}

The procedure for selecting measures and devices is a particularly important and complex part of the planning, design, and implementation of a safe infrastructure for cyclists. The model of selecting interventions and measures aimed at increasing the safety of cyclists in road traffic is presented in the Figure 1.

The model consists of 3 main stages:

- Stage I-Diagnosis—analysis of the input data,

- Stage II-Measures planning,

- $\quad$ Stage III-Implementation and monitoring. 
Selection of interventions and activities increasing the safety of cyclists in the road traffic

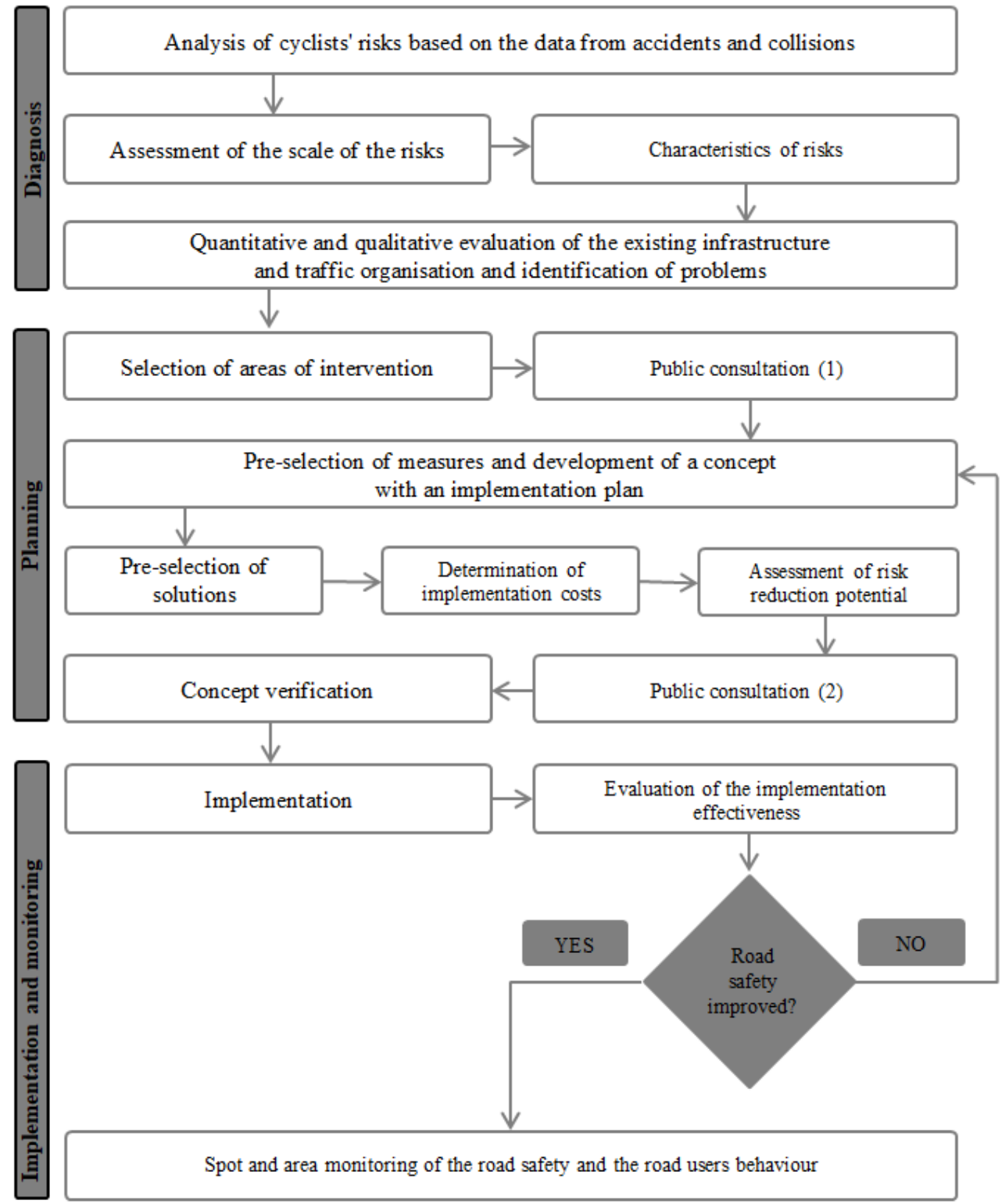

Figure 1. Model of selecting interventions and activities aimed at increasing the safety of cyclists in the road traffic [18].

Stage I-Diagnosis - the analysis of the input data includes the assessment of cyclists' hazards based on the data on accidents and collisions. The diagnosis makes it possible to define the characteristics of hazards as well as quantitative and qualitative assessment of the existing infrastructure and traffic organization (including the identification of problems). Road safety analyses use data published by the Central Statistical Office, the Police, the National Road Safety Council, and the Polish Road Safety Observatory operating at the Motor Transport Institute. Additionally, in the case of planning measures dedicated to improving the safety of cyclists, the basis for their selection should be the diagnosis of the road safety situation of this group of road users, as well as identification of their preferences in route selection (e.g., on the basis of surveys [38] or data collected from mobile phones [9]). Based on the data collected, it is necessary to assess the risk of road incidents involving cyclists and select places/areas that should be subject to interventions necessary to increase the safety of cyclists. The subject of analysis should be the area with the greatest risk 
to cyclists at the province and then county level, and to determine the nature of road events in which cyclists participated. An example of analysis of the location of accidents involving cyclists in 2015-2017 on the road network of the Wielkopolskie Province is shown in Figure 2.

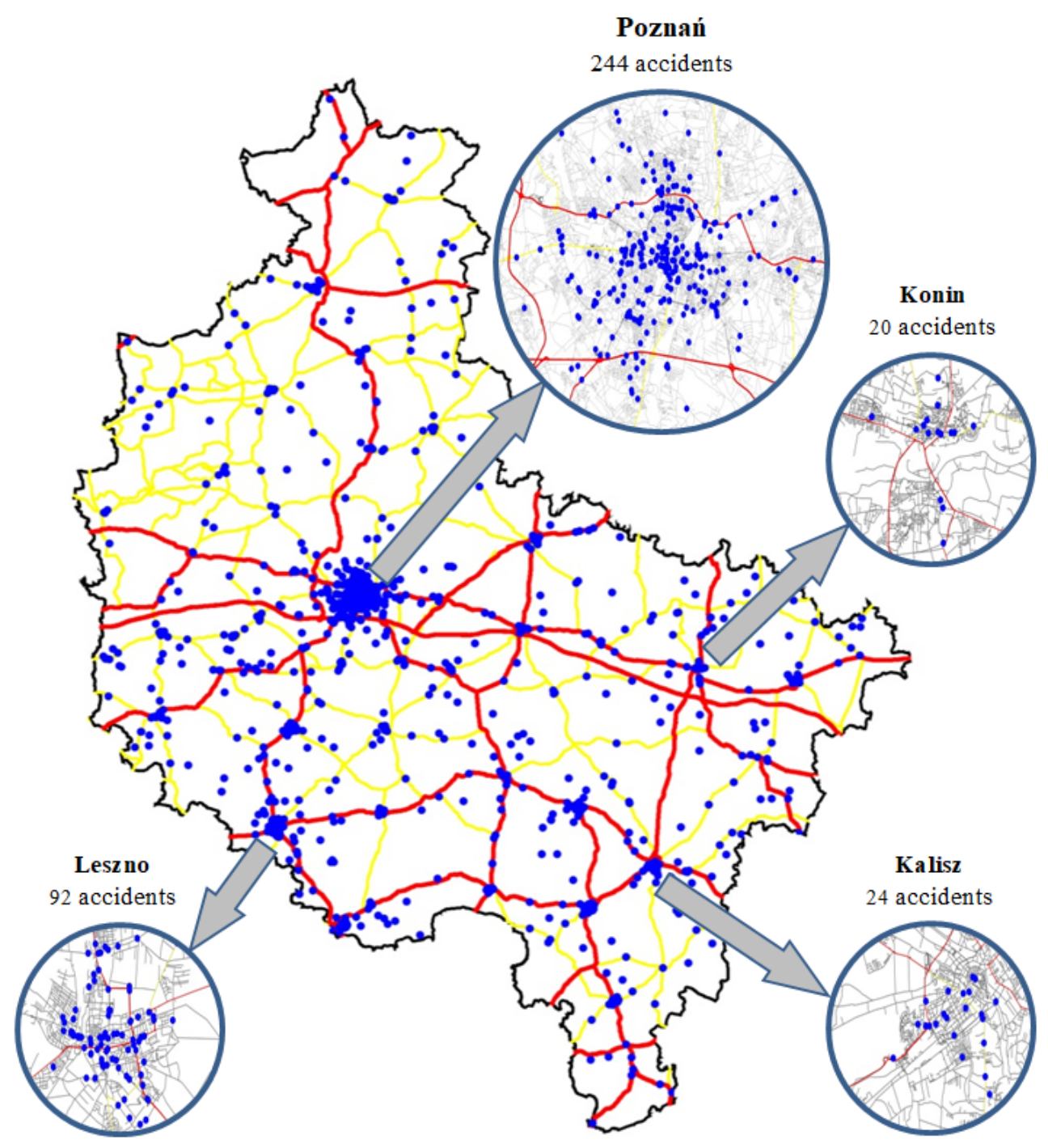

Figure 2. An example of an analysis of the location of accidents involving cyclists in 2015-2017 on the road network of the Wielkopolskie Province [18].

Stage II-Measures planning-includes selection of intervention areas, considering risk reduction and the effectiveness of planned activities and measures. Selected measures in a given area should be the subject of public consultations. Their aim is to obtain the views of bicycle user groups on the urgency and the need for actions. It is recommended that behavioral issues are considered in the action planning stage, as they can influence the choice of infrastructure type. For example, studies have indicated that commuter cyclists prefer on-street bike lanes over paths, because lanes are closely linked to the street network and provide more direct routes [39]. Spatial analyses of the identification of hazards and their characteristics do not always coincide with the opinions of users as to the scale of needs, and therefore, as a result of consultations, valuable information can be obtained, the acquisition of which may be difficult or even impossible in any other way. The next step is to pre-select measures along with an implementation plan. An integral part of this stage is determining the implementation costs and assessing the risk reduction potential. The initial 
concept developed—-together with the implementation plan—should be discussed again as part of public consultations and possibly verified in terms of the presented proposals and postulates.

Stage III-Implementation and monitoring-along with the implementation process, i.e., introducing the planned infrastructure and organizational solutions, evaluation is of particular importance, i.e., evaluation of the effectiveness of measures taken, which must answer the basic question about the degree of road safety improvement, in particular bicycle traffic. If the evaluation is positive, the spot and area monitoring of the road safety and road user behavior, including cyclists, should be introduced. Changes in safety and the relationship between the risk of cycling and the movement of other vehicles should be monitored. If the evaluation of the results is negative, it is necessary to return to the planning stage, i.e., verification of the pre-selected measures and the adopted concept, together with the implementation plan. In the case of a new set of selected solutions, the implementation costs should be determined and the potential for safety improvement should be evaluated. The verified scope of activities should be consulted with the public again before it is finally approved. After considering the proposals and conclusions, an updated concept is implemented.

The activities and selection of road safety devices should be carried out at different levels of management: central (strategic), provincial (tactical) and local (operational). The activities related to the safety of bicycle traffic include:

\section{At the central (strategic) level:}

- conducting periodic, nationwide diagnosis of cyclists' safety,

- monitoring achieving the cyclists' safety objectives, contained in the National Road Safety Program [20],

- amending legal acts relating to infrastructure and bicycle traffic,

- education on cycling in road traffic,

- development and dissemination of principles, recommendations, and methodologies for the organization of safe bicycle traffic and the creation of bicycle traffic development plans as well as manuals and studies with examples of "good practices".

2. At the provincial (tactical) level:

- conducting periodic provincial diagnosis of cyclists' safety,

- verification of the objectives and measures taken for the safety of cyclists included in the provincial road safety programs,

- allocating to the planned investment and organizational measures for the safety of cyclists an appropriate rank in the strategic documents of the province (province development strategies, regional strategic transport programs, regional operational programs, integrated territorial agreements),

- $\quad$ subjecting regional road (transport) projects to the road safety audits, with a focus on cyclists' safety,

- substantive and financial support (as part of the provincial financial plans) in the implementation of pilot projects by municipalities with the greatest risks to cycling.

3. At the local level (county, commune) in accordance with Figure 1:

- conducting periodic diagnosis of the safety of cyclists at the commune and county level,

- analyzing the availability of infrastructure for cyclists,

- creating plans for bicycle traffic programs and supporting the institutions (schools, workplaces, etc.) in creating safe cycling routes to public facilities,

- $\quad$ subjecting local road (transport) projects to the road safety audits, with particular emphasis on the safety of vulnerable road users, including cyclists,

- financial support for civic initiatives for the safety of cyclists (civic budgets in municipalities). 
Since the network of infrastructure for cyclists very often runs in various, adjacent administrative units, and its role is to enable travel between the city-destination zone, it is particularly important that activities related to the safety of cycling are integrated between individual counties and communes.

\section{Implementation and Monitoring of Selected Measures Aimed at Reducing Risk of Collisions/Accidents Involving Cyclists}

A cyclist safety program to be established at national, provincial, or local level should include a monitoring and evaluation plan (setting out objectives and indicators for assessing the effectiveness of cyclist safety measures).

It should include:

- evaluation of the road safety in actions taken, considering the migration of hazards,

- road safety analyses in places of intervention into the infrastructure intended for cyclists,

- research on the behavior and needs of road users, including cyclists,

- public consultations,

- preparing applications for the possible changes to the action plan,

- updating or developing a new action plan.

The results of monitoring cyclists' safety programs and the evaluation of interventions taken are crucial for the effectively achieving the objectives set, as well as for the improvement of the decision-making process, the exchange of experiences and the active participation of all stakeholders in the process of improving cyclists' safety.

\section{Summary and Discussion}

The growing role of the bicycle as a mode of transport, recreation and tourism has made it an integral part of the transport system of the cities, regions, and countries. National strategies assume a significant increase in the use of the bicycle as a mode of transport. The data about accidents involving cyclists in Poland presented in this paper may give rise to the question, whether it is a reasonable solution to encourage cyclists to ride on Polish roads? Would it not be an opposite effect to the expected one to increase the share of that vulnerable group of road users in road traffic? If the growing popularity of cycling is accompanied with the development of safe and functional transport infrastructure dedicated to that mode of transport, the danger for cyclists should decrease. However, the infrastructure provision only seems to be insufficient to achieve a higher level of cycling [40]. Choice of routes and location of transport infrastructure devices for cycling in the spatial structure and road and street network of cities and agglomerations is determined by the state of legal regulations on traffic, road and cycling infrastructure, landforms and socio-demographic characteristics of cyclists and their preferences in route selection. The method/concept proposed in this paper seems to be universal, because as it was shown in [38] that bicyclists around the world hold similar opinions on what improvements are required to promote cycling and enhance their experiences. Of course, country/region specificities, including legal or behavioral conditions or availability of some data, may require some modifications, such as skipping some steps of the proposed intervention selection model. It should be noted that the construction of infrastructure for cyclists is not the only way to improve the safety of this group of road users. Due to the high costs and deficit of the road surface in the road and street cross-section, other forms of activities in this area should also be used and the decisions should be made in accordance with applicable European standards and norms. However-due to the multitude of organizational and technical solutions available - the selection of interventions that increase the safety of cyclists is a very complex, multi-faceted task. Giving it a certain structure and creating an algorithm describing the procedure for selecting measures and devices and assessing the effectiveness of the implemented solutions, which is presented in the article, helps in making decisions and systematizing the order of work during the implementation of investments related to the bicycle traffic. However, an important obstacle in the process of taking right decisions 
about the development of cycling infrastructure may be the lack of necessary data about the number of journeys and cycling trips. Answers to the following key questions are often unknown: What is the amount of cycling traffic? What strategies will increase cycling? What are the benefits of increasing cycling? [41]. The use of new technologies, based on the data analysis generated, e.g., by mobile phones and navigation systems, which can be used for the development and monitoring of the cycling infrastructure system, can be very helpful [9]. The advantages of the use of new technologies should be appreciated, as they could be used for the creation of potential route rankings based on user preferences and the identification of cycling routes, which may improve safety as well as promote cycling.

An international experience has shown that concern for the safety of cyclists also contributes to reducing the risks to other road users. The growing popularity of bicycle traffic and concern for the protection of cyclists requires the creation of an appropriate bicycle infrastructure network that will meet the expectations of cyclists, will not cause conflicts with other road users, and most importantly, ensure road safety. In the countries where cycling is much more developed than in Poland, it was found that the greater the share of bicycles in moving about, the calmer (overall) road traffic becomes, which improves the safety of all road users [16,42]. It is estimated that this could have an impact of up to a $45 \%$ reduction in the number of road fatalities in the entire area where bicycle-friendly infrastructure has been established $[43,44]$.

Designing in a way that ensures the safety of cyclists guarantees greater diversity in the functioning of the street, which becomes friendlier for all users, because people are more visible on it and their behaviors more predictable [45].

Funding: This research received no external funding.

Institutional Review Board Statement: Not applicable.

Informed Consent Statement: Not applicable.

Conflicts of Interest: Author declares no conflict of interest.

\section{References}

1. Pucher, J.; Buehler, R.; Seinen, M. Bicycling Renaissance in North America? An Update and Re-Appraisal of Cycling Trends and Policies. Transp. Res. A Part Policy Pract. 2011, 45, 451-475. [CrossRef]

2. Dora, C.; Phillips, M. (Eds.) Transport, Environment and Health; WHO Regional Publications European Series; WHO: Copenhagen, Denmark, 2000; ISBN 978-92-890-1356-7.

3. Pucher, J.; Buehler, R.; Merom, D.; Bauman, A. Walking and Cycling in the United States, 2001-2009: Evidence from the National Household Travel Surveys. Am. J. Public Health 2011, 101 (Suppl. 1), S310-S317. [CrossRef] [PubMed]

4. Heydon, R.; Lucas-Smith, M. Making Space for Cycling. A Guide for New Developments and Street Renewals; Cyclenation: London, UK, 2014.

5. Kang, L.; Fricker, J.D. Bicyclist Commuters' Choice of on-Street versus off-Street Route Segments. Transportation 2013, 40, 887-902. [CrossRef]

6. Skoczyński, P. Rowerzyści. Available online: http://www.obserwatoriumbrd.pl/pl/analizy_brd/problemy_brd/rowerzysci1/ (accessed on 14 January 2021).

7. Knies, C.; Diermeyer, F. Data-Driven Test Scenario Generation for Cooperative Maneuver Planning on Highways. Appl. Sci. 2020, 10, 8154. [CrossRef]

8. Spooner, J.; Palade, V.; Cheah, M.; Kanarachos, S.; Daneshkhah, A. Generation of Pedestrian Crossing Scenarios Using Ped-Cross Generative Adversarial Network. Appl. Sci. 2021, 11, 471. [CrossRef]

9. Stamatiadis, N.; Pappalardo, G.; Cafiso, S. Use of technology to improve bicycle mobility in smart cities. In Proceedings of the 20175 th IEEE International Conference on Models and Technologies for Intelligent Transportation Systems (MT-ITS), Naples, Italy, 26-28 June 2017; pp. 86-91.

10. CROW. Sign Up The Bike; CROW: Ede, The Netherlands, 2001.

11. Groot, R. (Ed.) Design Manual for Bicycle Traffic; CROW-Record, Revised Edition; CROW: Ede, The Netherlands, 2016; ISBN 97890-6628-659-7.

12. Van den Berg, C. Brief Dutch Design Manual for Bicycle and Pedestrian Bridges; ipv Delft: Delft, The Netherlands, 2017.

13. Dufour, D. Promoting Cycling for Everyone as a Daily Transport Mode. PRESTO Cycling Policy Guide. Cycling Infrastructure; Ligtermoet \& Partners: Rotterdam, The Netherlands, 2010.

14. Dufour, D. Promoting Cycling for Everyone as a Daily Transport Mode. PRESTO Cycling Policy Guide. General Framewrok; Ligtermoet \& Partners: Rotterdam, The Netherlands, 2010. 
15. Urbanczyk, R. Promoting Cycling for Everyone as a Daily Transport Mode. PRESTO Cycling Policy Guide. Promotion of Cycling; Rupprecht Consult GmbH: Köln, Germany, 2010.

16. Andersen, T.; Bredal, F.; Weinreich, M.; Jensen, N.; Riisgaard-Dam, M.; Nielsen, M.K. Collection of Cycle Concepts 2012; Cycling Embassy of Denmark, Danish Road Directorate: København, Denmark, 2012.

17. Sustrans Design Manual. Handbook for Cycle-Friendly Design; Sustrans: Bristol, UK, 2014.

18. Dąbrowska-Loranc, M.; Cielecki, A.; Jasiński, A.; Skoczyński, P.; Zalewski, A.; Zielińska, A. Wytyczne Organizacji Bezpiecznego Ruchu Rowerowego. Podręcznik; Ministerstwo Infrastruktury-Sekretariat Krajowej Rady Bezpieczeństwa Ruchu Drogowego: Warszawa, Poland, 2018.

19. Instytut Rozwoju Terytorialnego. Standardy Projektowe i Wykonawcze dla Infrastruktury Rowerowej Województwa Dolnoślaskiego, 1st ed.; Instytut Rozwoju Terytorialnego: Wrocław, Poland, 2017; ISBN 978-83-944730-3-7.

20. Krajowa Rada Bezpieczeństwa Ruchu Drogowego. Narodowy Program Bezpieczeństwa Ruchu Drogowego Na Lata 2013-2020; Krajowa Rada Bezpieczeństwa Ruchu Drogowego: Warszawa, Poland, 2013.

21. Krajowa Rada Bezpieczeństwa Ruchu Drogowego. Krajowy Program Bezpieczeństwa Ruchu Drogowego 2005-2013. GAMBIT 2005; Krajowa Rada Bezpieczeństwa Ruchu Drogowego: Warszawa, Poland, 2005.

22. Komisja Europejska. W Kierunku Europejskiego Obszaru Bezpieczeństwa Ruchu Drogowego: Kierunki Polityki Bezpieczeństwa Ruchu Drogowego na lata 2011-2020; Komisja Europejska: Bruksela, Belgia, 2010.

23. European Commission. Directorate General for Mobility and Transport Next Steps towards "Vision Zero": EU Road Safety Policy Framework 2021-2030; European Commission: Brussel, Belgium, 2020; ISBN 978-92-76-13219-6.

24. Road Safety Authority. Road Safety Strategy 2013-2020; Road Safety Authority: Ballina, Irlandia, 2013.

25. Department for Transport. Strategic Framework for Raod Seafety; Department for Transport Great Minister House: London, UK, 2011.

26. Australian Transport Council. National Road Safety Strategy 2011-2020; Australian Transport Council: Canberra, Australia, 2011.

27. Ministry of Transport. Road Safety Strategic Plan 2008-2020. From, for and by Everyone; Ministry of Transport; Public Works and Water Management: Hague, The Netherlands, 2009.

28. Norwegian Public Roads Administration. National Plan of Action for Road Safety 2018-2021. Short Version.; Norwegian Public Roads Administration: Oslo, Norway, 2018.

29. World Health Organization. Decade of Action for Road Safety 2011-2020; World Health Organization: Geneva, Switzerland, 2011.

30. Jamroz, K.; Michalski, L.; Gaca, S. Road safety programmes as an effective tool for developing system-based road safety policies. J. Konbin 2006, 1, 153-160.

31. Elvik, R.; Vaa, T.; Erke, A. Handbook of Road Safety Measures; Emerald Group Publishing Limited: Bradford, UK, 2009; ISBN 978-1-84855-251-7.

32. Jamroz, K. Ochrona Pieszych: Podręcznik dla Organizatorów Ruchu Pieszego: Praca Zbiorowa; Ministerstwo Infrastruktury i RozwojuSekretariat Krajowej Rady Bezpieczeństwa Ruchu Drogowego: Gdańsk, Polska, 2014; ISBN 978-83-7610-527-7.

33. Świderski, A.; Borucka, A. Mathematical Analysis of Factors Affecting the Road Safety in Selected Polish Region, Transport Means. In Proceedings of the 22nd International Scientific Conference Part II, Lithuania; Kaunas University of Technology: Trakai, Lithuania, 2018; pp. 651-654.

34. Skoczyński, P. Rowerzyści. Skala Problemu. Available online: http://www.obserwatoriumbrd.pl/pl/analizy_brd/problemy_ brd/rowerzysci1/skala_problemu/ (accessed on 14 January 2021).

35. Borucka, A.; Kozłowski, E.; Oleszczuk, P.; Świderski, A. Predictive Analysis of the Impact of the Time of Day on Road Accidents in Poland. Open Eng. 2020, 11, 142-150. [CrossRef]

36. Świderski, A.; Borucka, A.; Skoczyński, P. Characteristics and Assessment of the Road Safety Level in Poland with Multiple Regression Model. In Proceedings of the Transport Means 22nd Interna tional Scientific Conference, Trakai, Lithuania, 3-5 October 2018; pp. 92-97.

37. Sandecki, T. Komentarz Do Warunków Technicznych, Jakim Powinny Odpowiadać Drogi Publiczne i ich Usytuowanie. Cz. 2; Biuro Projektowo-Badawcze Dróg i Mostów “Transprojekt-Warszawa": Warszawa, Polska, 2002; ISBN 978-83-903370-5-0.

38. Stamatiadis, N.; Cafiso, S.; Pappalardo, G. A Comparison of Bicyclist Attitudes in Two Urban Areas in USA and Italy. In Data Analytics: Paving the Way to Sustainable Urban Mobility; Nathanail, E.G., Karakikes, I.D., Eds.; Advances in Intelligent Systems and Computing; Springer: Cham, Switzerland, 2019; Volume 879, pp. 272-279. ISBN 978-3-030-02304-1.

39. Dill, J.; Carr, T. Bicycle Commuting and Facilities in Major U.S. Cities: If You Build Them, Commuters Will Use Them. Transp. Res. Rec. J. Transp. Res. Board 2003, 1828, 116-123. [CrossRef]

40. Parkin, J.; Wardman, M.; Page, M. Estimation of the Determinants of Bicycle Mode Share for the Journey to Work Using Census Data. Transportation 2007, 35, 93-109. [CrossRef]

41. Handy, S.; van Wee, B.; Kroesen, M. Promoting Cycling for Transport: Research Needs and Challenges. Transp. Rev. 2014, 34, 4-24. [CrossRef]

42. Adminaité-Fodor, D.; Jost, G. How Safe Is Walking and Cycling in Europe? PIN Flash Report 38; European Transport Safety Council: Brussels, Belgium, 2020; p. 68.

43. Road Safety Observatory. Cycling Infrastructure Observatory Main Category: Roads. Available online: https://www. roadsafetyobservatory.com/Review/10143 (accessed on 14 January 2021). 
44. European Commission. Traffic Safety Basic Facts on Cyclists; European Commission, Directorate General for Transport: Brussels, Belgium, 2018; p. 24.

45. Sadik-Khan, J.; Mincer, W.; Żakowska, M.; Solomonow, S. Walka o Ulice: Jak Odzyskać Miasto dla Ludzi; Wysoki Zamek: Kraków, Poland, 2017; ISBN 978-83-947365-2-1. 